\title{
Stapled Securities: Antipodean Anomaly or Adaptable Innovation?
}

\author{
Kevin Davis* \\ Research Director, Australian Centre for Financial Studies \\ Level 43, 80 Collins St. \\ Melbourne, Vic 3000 \\ Australia \\ Professor of Finance, University of Melbourne (on leave) \\ Professor of Finance, Monash University \\ kevin.davis@australiancentre.com.au \\ Ph: (+61) 0409970559
}

\begin{abstract}
The issuing of stapled securities (such as a unit in a trust and a share in a company) which cannot be traded separately occurs relatively frequently in Australia but is not common elsewhere. This paper outlines the features and usage of stapled security structures and examines explanations for their popularity in Australia such as tax, behavioral finance, and governance aspects. It considers the use of such structures, and regulatory impediments, in other economies.
\end{abstract}

Keywords:

Stapled Securities, Financial Innovation, Taxation, REITs, Infrastructure Funds

JEL Codes: G32

\footnotetext{
* I am grateful to Patrick Zhang for research assistance.
} 


\section{Introduction}

Stapled security structures have been used frequently in Australia by a range of issuers including Australian Real Estate Investment Trusts (AREITS) ${ }^{1}$, Infrastructure Funds ${ }^{2}$, and major banks. These structures involve two or more securities issued by the same or different entities being contractually bound together such that they cannot be traded separately. While there are many different types of structures, stapling ${ }^{3}$ together of units in a trust and shares in a company has been common practice by AREITS and Infrastructure Funds, while a number of major banks have issued stapled hybrids involving stapling of a "loan note" issued by an offshore branch of the bank to a preference share issued by the parent. Although originating originally in the USA, legislation in that country has inhibited their use.

For two reasons, the use of such stapled structures in Australia appears anomalous. First, absent other market imperfections, imposing a restriction that two individual securities cannot be traded (or held) separately would be expected to reduce their aggregate market value. Second, while tax considerations are an important market imperfection which might lead to value creation from stapling, the Australian dividend imputation tax system removes or reduces the potential for such value creation in the majority of cases where stapling has been used. Hence, other explanations for the popularity of stapling must be sought. In contrast, recent growth in popularity in Canada is readily attributable to tax reasons and has led to legislation in 2011 to prevent such tax arbitrage.

This paper proceeds as follows. First, the concept of stapling is explained in more detail and information on its usage in Australia is provided. Second, potential sources of value creation underpinning use of stapling are considered. Third, international experience with stapling is examined, including analysis of reasons for its regulatory prohibition and potential for future applicability. Finally, implications for regulatory and tax policy are considered in the concluding section.

\footnotetext{
${ }^{1}$ In March 2008, the ASX adopted the term A-REIT in place of the previously used Listed Property Trust.

${ }^{2}$ Infrastructure Funds are managed investment schemes which hold and manage infrastructure assets such as airports, gas pipelines etc. See Davis (2009) for an analysis of their financial management practices.

${ }^{3}$ It is important to note that the practice of stapling considered here is different to that analyzed by Povel and Singh (2010) which refers to vendors of a company also providing in the sale contract an option for the purchaser to access debt from a third party.
} 


\section{Stapling: Concept and Uses}

There are many different variants of stapled securities, ranging from those involving different securities issued by a single entity to those involving securities issued by a number of different entities. Figure 1 provides a simple example of a stapled security involving only one entity, with stapling of loan notes (debt securities) to shares, such as was used in the spin-off of the energy company Envestra by Boral Ltd in 1997. Investors receive an income stream comprising dividends, interest and a return of principal - each component of which (under the Australian tax system) involves different tax treatment. Over time the mix of these components can vary, and the terms of the loan note provide corporate management discretion regarding amounts to be distributed.

\section{Figure 1: Stapled structure involving one company}



A second form of stapling (of which there are many variants), predominantly used by AREITS and Infrastructure Funds, involves stapling together units in a trust and the shares in an associated company. ${ }^{4}$ Figure 2 illustrates a simple case where the stapling agreement involves the trust leasing the assets it owns to the company for its use to

\footnotetext{
${ }^{4}$ There are a number of instances where the stapling involves more than two entities (two trusts and one company, or one trust and two companies), but the stapling of one trust and one company is by far the most common.
} 
generate income in return for a rental payment. ${ }^{5}$ In the case of Infrastructure Funds, the structure often involved the trust's assets being all the equity of a number of operating businesses, such as airports or power utilities, with management of those businesses being the responsibility of the stapled company.

\section{Figure 2: Stapled Structure using a company and trust}

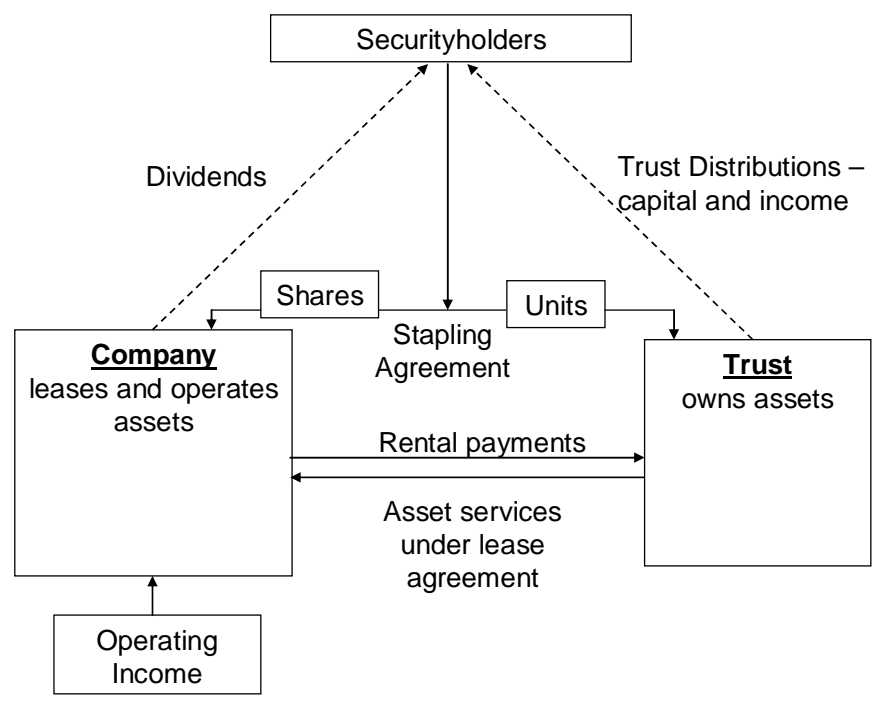

In principle, this structure provides for internal management of the assets and other development activities by the operating company, while the holders of the stapled securities are owners of the operating company and have voting rights to determine membership of its board. However, in practice, the creation of the stapled structure generally also involves an external manager which is the responsible entity (RE) of the trust under the relevant Australian legislation, and which is also likely to have control of the board of the operating company via the existence of special shares (or through initial appointments and subsequent board entrenchment). ${ }^{6}$ In these circumstances, the stapled

\footnotetext{
${ }^{5}$ Other structures could involve the trust making a loan to (or purchasing preference shares issued by) the company such that the latter could purchase and own the assets.

${ }^{6}$ Riskmetrics (2008) provides more detail.
} 
company may have few operational activities with management being outsourced by it to, or services being purchased from, the external management company.

Figure 3 illustrates the case where both the external manager appointed by the operating company and the Responsible Entity for the trust are subsidiaries of the firm which created the structure. (Listed investment banks such as Macquarie Bank and (the now defunct) Babcock and Brown were significant creators of such structures). The creator of the structure receives fee income both from its roles as an RE of the trust and as the external manager appointed by the company.

\section{Figure 3: Stapled Structure and Role of External Manager}

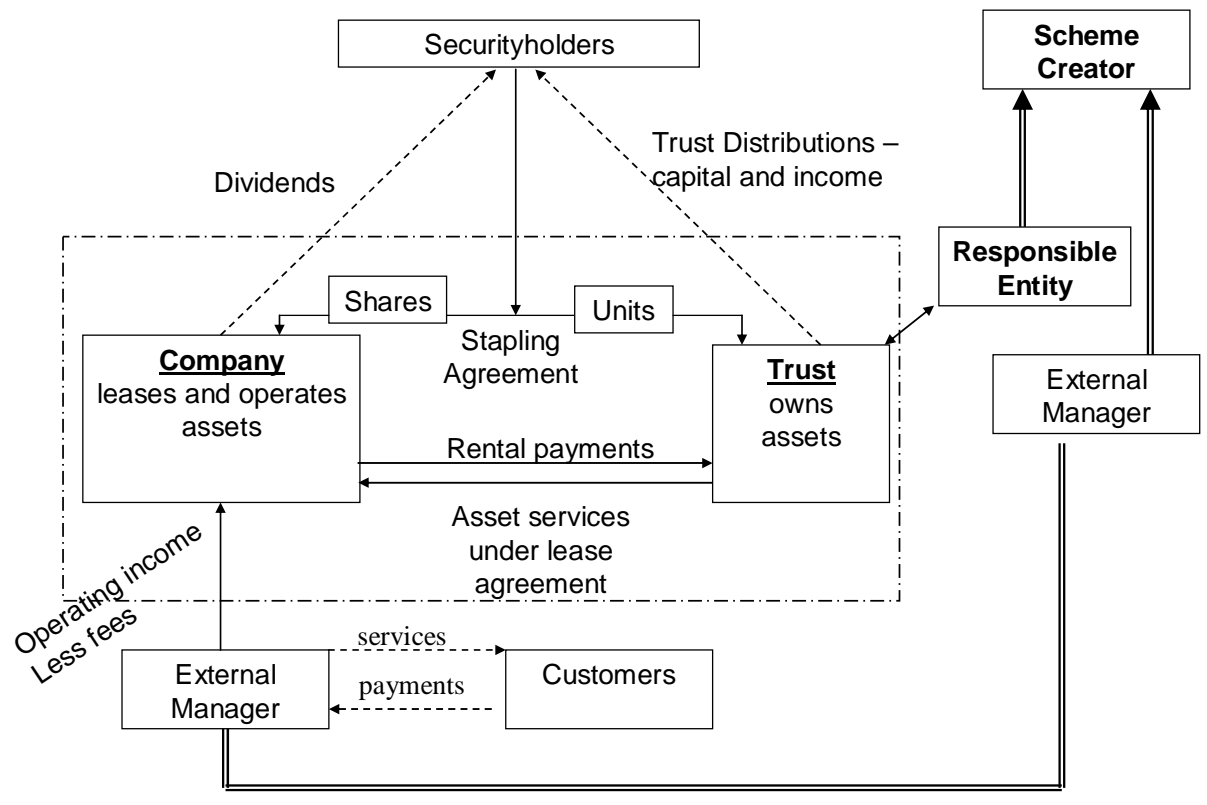

The third form of stapled structure which has been adopted by several of the major Australian banks involves stapling together a loan note issued by an overseas subsidiary or branch of the bank with a preference share issued by the bank. The preference share pays no dividend, and the loan note pays an income stream which is linked to some market indicator rate (the bank bill swap rate) ${ }^{7}$ but which also carries with it franking (tax) credits. At a specified mandatory conversion date, the stapled security is redeemed for cash (although other outcomes are possible). Consequently, the stapled security has

\footnotetext{
${ }^{7}$ The bank bill swap rate (BBSW) is the short term rate for the Australian market (analagous to LIBOR).
} 
the characteristics of a floating rate note to which tax credits (which have differential value to taxpayers on different personal tax rates) are attached. Figure 4 provides a generic illustration.

Figure 4: Stapling involving Bank parent and subsidiary

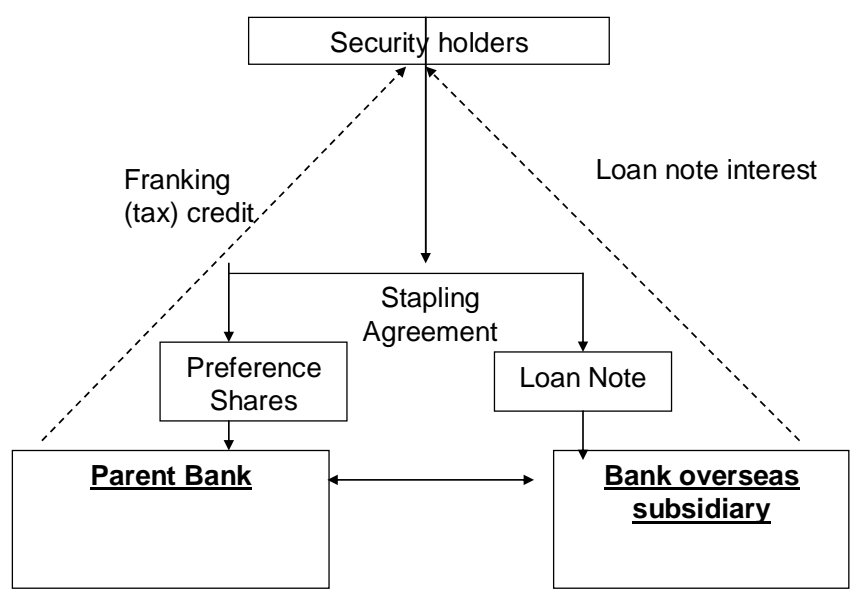

The first stapled securities structure in Australia was for the creation of a property trust (A-REIT) by Stockland Group in 1988. Prior to 2000, only another five infrastructure trusts/ A-REITS used a stapled securities structure. ${ }^{8}$ However, over the next few years the structure became popular such that by April 2008, there were 50 Stapled Securities listed on the Australian Securities Exchange. The introduction of the Managed Investments Act in 1998 which removed the requirement for a separate trustee for managed funds, and the introduction of a sole Responsible Entity (RE) facilitated this development, by indirectly providing greater opportunities for investment banks and other financial firms to develop innovative financial structures.

Most of those earlier issues involved Property Trusts (A-REITS) and Infrastructure Funds, with 46 out of 50 Stapled Securities at April 2008 being within those sectors. Table 1 shows the percentage, by value, of A-REITS and Infrastructure Funds using a

\footnotetext{
8 Thakral Holdings Group (1994), Transurban (1996), Macquarie Infrastructure (1996), Envesta (1997), Mirvac (1999).
} 
stapled security structure, and Appendix 1 provides a listing of stapled securities as at that time.

Table 1: A-REIT and Infrastructure Funds, Stapled Securities, April 2008

\begin{tabular}{|l|l|l|}
\hline Sector & $\begin{array}{l}\text { Market Cap (\$ } \\
\text { mill) }\end{array}$ & $\begin{array}{l}\text { Percentage using stapled } \\
\text { security structure }\end{array}$ \\
\hline A-REITs & 103,130 & $60 \%$ \\
\hline Infrastructure Funds & 41,990 & $24 \%$ \\
\hline Total Limited Managed Investments & 171,864 & \\
\hline
\end{tabular}

At the end of 2011, 15 out of 18 listed infrastructure funds and 28 out of 49 listed AREITs had stapled security structures. ${ }^{9}$

Over the past decade, Australian banks have created hybrid securities using stapled structures such as that shown in Figure 4 to raise around $\$ 10$ bill of capital. Table 2 provides a list of stapled securities issued by Australian banks, some of which pay distributions with franking (tax) credits attached, while others pay unfranked dividends. In general, there is a mandatory conversion date into a fixed value of ordinary equity (or redemption).

Table 2: Australian Bank Stapled Security Issues

\begin{tabular}{|l|l|l|l|l|l|l|}
\hline $\begin{array}{l}\text { ASE } \\
\text { Ticker }\end{array}$ & Issuer & $\begin{array}{l}\text { Security } \\
\text { Name }\end{array}$ & Issue Date & $\begin{array}{l}\text { Amount } \\
(\$ \text { bill })\end{array}$ & Coupon* & $\begin{array}{l}\text { Conversion } \\
\text { Date }\end{array}$ \\
\hline CBAPB & CBA & PERLS V & $14 / 10 / 09$ & 2 & (BBSW+3.4)(1-t) & $31 / 10 / 14$ \\
\hline CBAPA & CBA & PERLS IV & $6 / 7 / 07$ & 1.465 & $($ BBSW+1.05)(1-t) & $31 / 10 / 12$ \\
\hline WBCPA & WBC & SPS & $31 / 7 / 08$ & 1.04 & $(B B S W+2.4)(1-t)$ & $26 / 9 / 13$ \\
\hline WBCPB & WBC & SPSII & $31 / 3 / 09$ & 0.908 & $(B B S W+3.8)(1-t)$ & $30 / 9 / 14$ \\
\hline ANZPA & ANZ & StEPS & $24 / 9 / 03$ & 1 & BBSW+1.0 & $5 / 9 / 08$ \\
\hline NABHA & NAB & NIS & $29 / 6 / 99$ & 2 & $(B B S W+1.25)$ & Perpetual \\
\hline n.a. & NAB & $\begin{array}{l}2008 \text { Stapled } \\
\text { Securities }\end{array}$ & $24 / 9 / 08$ & 0.3 & BBSW+2 & $24 / 9 / 12$ \\
\hline n.a. & NAB & $\begin{array}{l}2009 \text { Stapled } \\
\text { Securities }\end{array}$ & $30 / 9 / 09$ & 0.5 & BBSW+2 & $30 / 3 / 11$ \\
\hline
\end{tabular}

* Those securities where the coupon is multiplied by (1-t), where $t$ is the corporate tax rate, pay franked distributions.

\section{$2 \quad$ Value Creation through Stapled Securities}

In general, investors should prefer to have two securities which can be separately traded rather than stapled - unless the act of stapling increases the value of their investment.

\footnotetext{
${ }^{9}$ http://www.asx.com.au/products/managed-funds-product-list.htm (accessed 13/1/12)
} 
Hence, it is important to address the question of how stapling might create value, thereby leading managers of the entities involved to adopt stapled structures. Alternatively, stapling may involve no aggregate value creation, but in an environment of imperfect information or behavioral biases, the restrictions imposed by stapling may enable issuers of such securities to extract higher prices from investors.

Financial innovation can be prompted by a range of market imperfections such as taxes, regulation, imperfect information and transactions costs. Appropriate security design may enable tax arbitrage, regulatory arbitrage, signaling of value or risk, improved monitoring/reduced agency costs, increased liquidity, and/or expansion of the opportunity set for some agents by creation of packages of cash flows with desired risk characteristics which those agents are unable to construct themselves due to transactions costs. ${ }^{10}$ Promoters of such structures may also exploit investor irrationality, behavioral biases or imperfect information to create wealth transfers by selling overpriced securities. Given the variety of stapled structures shown above, some of these motives may apply in some cases but not others.

\section{Tax Arbitrage}

Of the three types of stapled structures outlined earlier, tax arbitrage is potentially relevant to the latter two cases (illustrated in Figures 2 (or 3) and 4) involving stapling of securities issued by different entities subject to differential taxation arrangements. ${ }^{11}$

Consider first the stapling of a non-operating trust and a company. Such "non-operating" trusts are treated as "pass-through" for tax purposes, such that (provided income is distributed to unit holders) no tax is paid by the trust and the income is taxed in the hands of the investors. In contrast, company income is taxed at the company level. ${ }^{12}$ In the example provided earlier (Figure 2), the taxable income of the company component is reduced by rental/lease payments to trust, hence leading to a lower company tax bill than

\footnotetext{
${ }^{10}$ Finnerty and Emory (2002) examine a large number of corporate financial innovations examining potential sources of value added of: enhanced liquidity; reductions in transactions costs; risk reallocation; reduced agency costs, tax and other benefits.

${ }^{11}$ There are no discernible tax benefits from stapling together debt and equity of the same issuer unless the tax code involves differential tax treatment of each (as in a classical tax system) and regulation does not prevent "disguising” an effective equity investment as debt.

${ }^{12}$ The Australian Tax Office requires that investors treat each component of a stapled security as a separate security for taxation purposes.
} 
if a company structure or an operating trust structure was used. In a classical tax system, this reduction in company tax would be a source of (private) value creation, but not so under the Australian dividend imputation tax system in which company tax is "washed out” by distribution to Australian shareholders of tax credits attached to dividends. Only for non-resident investors would there be tax benefits due to their inability to use such tax credits. Since most investors in A-REITS are residents, tax arbitrage does not provide a good explanation for use of this structure.

In contrast, tax arbitrage appears to be an important determinant of the use of stapling by Australian banks (see Figure 4). Income earned by their foreign branches or subsidiaries will be subject to foreign tax rather than Australian $\operatorname{tax}^{13}$, and thus not generate Australian tax (franking) credits for distribution with dividends by the Australian parent. However, interest paid on the loan note by the foreign branch will reduce its taxable income and thus foreign company tax paid. While more Australian company tax may be paid on earnings from the use of the funds raised by the parent bank, this generates tax (franking) credits which can be attached to the distributions on the stapled security. Because these securities were only offered domestically, the creation of tax credits useable by domestic investors, by reducing foreign company tax paid and increasing Australian company tax paid, creates value for shareholders. ${ }^{14}$

\section{Expansion of the Investor Opportunity Set}

The hybrid securities created by banks stapling of (foreign issued) loan notes and preference shares provide a good example of value creation through expansion of the investor opportunity set (although this is based on tax arbitrage). Because of the nature of the dividend imputation tax system, investors on tax rates below the corporate tax rate are able to use tax (franking) credits received to reduce tax payable on other income. Australian superannuation (pension) funds fall into this category. ${ }^{15}$ To gain that tax benefit, it is generally necessary to invest in dividend paying shares creating an exposure to company share prices. However, the stapled securities provide a (floating rate) bond

\footnotetext{
13 The precise arrangements will depend upon the tax treaties between the host and home countries.

14 The New Zealand Government reacted to this potential dilution of the tax base by passing legislation in 2009 causing stapled debt to be treated as equity for tax purposes. See Inland Revenue NZ (2009).

15 The tax rate for superannuation funds is 15 per cent compared to a corporate tax rate of 30 per cent.
} 
type return together with tax (franking) credits. Consequently, they are particularly attractive to low tax rate investors who do not want increased equity exposure to the issuing bank.

Another example of value creation via expansion of the opportunity set can be found in the case of issuance of stapled debt (loan notes) and equity in the spin-off of energy company Envestra by Boral (such as in illustrated in Figure 1). With large depreciation allowances, the company would have substantially positive cash flow, but negative earnings for some years, limiting its legal ability to pay dividends to shareholders. However, by stapling, cash could be returned to investors via payments of interest and capital on the loan note component (and the terms of the loan note gave management discretion on the amounts to be paid).

A further way in which investor opportunities may be expanded is if financial innovations enable a weakening of institutional constraints on portfolio selection. In this regard, many fund managers operate separate fixed interest and equity funds, raising the question of whether A-REITS should be viewed as closer substitutes for debt or equity. Yong (2010) examines whether there are differences in the return behavior of stapled and traditional A-REITS, recognizing that the business activities contained within the stapled A-REITS are likely to increase return correlation with the equity market. Evidence is found of cointegration of stapled A-REIT and equity market returns, whereas traditional A-REIT returns are cointegrated with bond market returns. In both cases, direct property returns are relevant to short-run adjustment processes.

\section{Regulatory Arbitrage}

Financial innovation may be used to avoid particular regulatory restrictions, or minimize their adverse impact on profitability by designing security structures which enable compliance with regulation at lower cost. The issuance of stapled securities by Australian banks is an example of this practice. The stapled securities listed in Table 2 all qualified as Tier 1 non-innovative residual capital for the purposes of meeting the Basel Accord capital requirements. Hence, rather than issuing equity to increase regulatory capital, the 
banks were able to issue a floating interest rate note which, arguably, has a lower cost of capital for the banks. ${ }^{16}$

\section{Real Efficiencies}

Stapled securities horizontally integrate several businesses into one structure via the contractual agreements between them. This may provide benefits from synergies (shared expertise and knowledge), "internalization” of certain transactions rather than use of the market, increased certainty due to the long-term contracts involved and consequent removal of the "hold-up" problem. Certainly the stapled structures allow "internal management" of A-REITs and infrastructure funds, and the tax benefits of a trust component within an entity undertaking operating (rather than purely investing) activities (possibly not permissible under a standard (non-stapled) A-REIT structure. But whether stapled structures have performed better than non-stapled structures is a moot point. Newell and Peng (2009) argue that non-stapled A-REITs performed better during the global financial crisis (although their analysis is based on comparisons using a very small sample of non-stapled A-REITS).

\section{Behavioral Biases}

The literature on behavioral finance has illustrated that investor behavior can be affected by the way in which financial products are "framed". In particular, investors may be unwilling to spend out of capital, but may not perceive certain cash flow streams from investments as being repayments of capital invested, and interpret the total cash flow as a rate of return or yield on the security. ${ }^{17}$

Exploitation of this behavioral bias is relevant to both the stapling of trust units and company shares and stapling of debt securities (loan notes) and shares of the same company. In both cases, some component of the cash flow return (trust distributions or loan note payments) is, in fact, a repayment of principal. Yet it is apparent, from financial

\footnotetext{
${ }^{16}$ Miller (1995) discusses whether the Modigliani-Miller capital structure irrelevance proposition might apply to banks, with implicit or explicit government guarantees over deposits being one reason for nonapplicability. Australian bankers certainly view equity as the most expensive form of capital, even though the dividend imputation tax system works to eliminate or reduce double taxation of dividends, and Blake Dawson (2010) state that "[t]hese instruments are a cost effective and efficient way to raise capital".

${ }^{17}$ Shefrin and Statman (1993) provide a good illustration of this effect in an analysis of covered call writing by individual investors.
} 
planning and investment advice literature that investors consider the total cash flow as the "rate of return" or "yield" of the stapled security. This is reinforced by the unusual language used by the Australian Tax Office in referring to returns of capital as "taxdeferred income”, on which no current tax is payable but which leads to a reduction in the cost-base of the security used in calculation of capital gains when it is sold.

To the extent that such behavioral biases exist, stapling could be used to reduce IPO underpricing. If potential investors interpret projected cash flow returns as a "yield" rather than as a mix of income and capital repayment, their willingness to pay a higher price may reduce underpricing. On the other hand, stapled A-REITS may, because of the business activities of the stapled company, be of higher risk and less easy for potential investors to value, leading to greater underpricing. Dimovski (2010) examines this possibility in a study of A-REIT IPOS from 2002-2008 and finds no statistically significant difference in the degree of underpricing between stapled and non-stapled structures.

A further rationale for stapling, relative to separate issuance of trust units and equities or debt, may arise from institutional anomalies in stock market and funds management practices. Specifically, market capitalization of the listed entity is calculated by the ASX as the total value of the stapled securities on issue. Consequently a stapled structure will be regarded as "larger" than a similar structure with unstapled securities - for which only units or shares, but not debt, would be included in the size calculation. It is well known that there are share price benefits in terms of inclusion in market indices of larger stocks due to fund manager performance benchmarking. Hence an apparently larger size due to stapling may increase demand for the entities securities, enabling issuance at a higher price. In this regard, greater liquidity associated with larger market capitalization may also be beneficial.

\section{Resolution of Agency Issues}

Jensen (1988) discusses stapling of securities in the context of "strip financing" in leveraged buyout transactions, noting that "[s]trip financing, the practice in which risky nonequity securities are held in approximately equal proportions, limits the conflict of interest among such securities’ holders and therefore limits bankruptcy costs.” He notes 
that in a highly levered structure where securities are stapled, the control rights associated with the debt components may provide investors with greater powers, than in an all equity structure, to prevent managers from using free cash flow for value destroying investments rather than making distributions. It also reduces conflicts between equity and debt holders and reduces resolution problems in bankruptcy. ${ }^{18}$ However, Jensen also notes that "[s]trictly proportional holdings of all securities is not desirable, for example, because of IRS restrictions that deny tax deductibility of debt interest in such situations" but that "riskless senior debt needn’t be in the strip".

One potential benefit of reduced agency costs from stapling in the case of A-REITs and infrastructure funds comes from the internalization of management functions for the trust. Rather than management being outsourced to a separately owned Responsible Entity, stapling can mean that the trust and management company share common ownership thereby reducing potential agency problems - particularly if unit holders in the trust have limited ability to replace the external manager.

Many of the A-REIT and infrastructure fund stapled structures involve substantial external leverage, suggesting some similarity with the case discussed by Jensen. However, because of the use of trusts in which distributions are at the discretion of the manager (the Responsible Entity), there are limited control rights available to the investors other than exit (sale of securities) or voice (voting for replacement of the manager). However, the nature of the governance structures put in place and discussed below appear to have rendered the latter infeasible, and suggest that agency problems are aggravated rather than ameliorated.

\section{Entrenchment and Wealth Transfers}

Some commentators (RiskMetrics, 2008) have argued that investment banks such as Macquarie Bank and (the now defunct) Brown and Babcock, have exploited the opportunities available in trust structures for entrenching managerial fee generating roles and extracting wealth at the expense of investors. For example, in some cases, arrangements involved in the stapling structure included a "poison pill" of the form that

\footnotetext{
${ }^{18}$ Reduction of bankruptcy resolution problems may also be relevant in the case of stapling of securities from different issuers (compared to full integration of activities in one entity) by "ring fencing" of liquidation risk such that failure of one issuer does not imply failure of its stapled partner.
} 
should unit holders in the trust vote to remove the manager (either via removing the RE or ending the management contract with the stapled operating company) ongoing payments of the management fee would still be required.

Also relevant in this regard is the fact that Australian legislation does not require the management agreement between the trust and operating entity to be disclosed (other than a minimal summary in the offer documents). RiskMetrics (2008) is particularly critical of this deficiency, and of the unwillingness of Responsible Entities such as Macquarie Bank to make such documents available to investors or third parties.

The issuance of stapled debt and equity by the same company may also promote entrenchment by increasing the funds required for a takeover (relative to that involved for a company with a similar, but non-stapled, capital structure). To purchase a controlling stake in the company, stapling requires the potential acquirer to outlay sufficient funds to purchase both equity and debt components. Whether this increase in the scale of the transaction required to achieve control is an effective deterrent to acquisition is unclear.

\section{International Dimensions}

Stapled security structures were developed and used in the USA until changes to the Internal Revenue Code in 1984 were made following growing use by REITs which were aimed at carrying on active businesses, rather than pure investment activities, while still maintaining the essentially flow-through tax treatment afforded to REITs. Avi-Yonah, Edgar and Shaheen (2007) provide examples of how stapled security structures were developed to avoid legislation aiming to prevent tax arbitrage resulting from deferral of remittances of income from foreign companies. One such structure was for a US company with overseas operations to create a foreign company whose shares were stapled to the US company's shares rather than creation of a subsidiary. The US legislation precludes a stapled REIT from flow-through tax treatment, treats stapled foreign corporations as domestic corporations (thereby eliminating any tax deferral 
benefits), and treats a domestic stapled corporation as a subsidiary of the controlling company to which it is stapled. ${ }^{19}$

Generally stapled securities have been a relatively rare international phenomenon, but found growing use in Canada as an alternative mechanism for achieving the tax arbitrage opportunities of income trusts following legislation (the Tax Fairness Plan) in 1986 attempted to limit. In essence, the income trust structure was developed to arbitrage the tax system by a trust holding both equity and "internal" debt of a highly leveraged operating company. ${ }^{20}$ Interest expenses reduce tax paid by the company, while the trust's receipts of interest are not taxed at the trust level if distributed to unit holders. Consequently, double taxation of dividends as occurs under a classical or non-integrated tax system is avoided. Avi-Yonah, Edgar and Shaheen (2007) provide more details and examples of more complex structures, and outline how loss of tax revenue when investors in income trusts are tax exempt or foreign investors prompted legislation to essentially subject such income to dividend taxation at the trust level. They argue that this response does not preclude investors achieving the same tax arbitrage by use of structures such as stapled securities involving investors holding debt of a highly leveraged operating company which is stapled to units in a trust which holds the equity of the operating company. $^{21}$

Halpern and Norli (2006) also discuss the structure of Canadian business trusts (which they identify as a subset of income trusts), as well as the development of Income Participating Securities (IPS) and Income Depository Securities (IDS) as quasi-stapled structures which enabled US companies or trusts to list on the Toronto exchange. To meet both US and Canadian regulatory requirements, debt and equity of the issuing company were "clipped" together (rather than stapled) enabling subsequent separation, and some amount of external subordinated debt required to be separately issued. Halpern and Norli note that "both structures have been largely unsuccessful in attracting

\footnotetext{
${ }^{19}$ In the UK, the "worldwide debt cap” rules, which aim to prevent excessive interest tax deductions against UK income by multinational companies also apply to companies with stapled structures. (HM Revenue and Customs, 2010).

${ }^{20}$ See Avi-Yonah, Edgar and Shaheen (2007) and also Alarie and Iacobucci (2007), who note that "[i]n substance trust units are like a stapled security".

${ }^{21}$ They also present an example similar to that in Figure 2 where the trust owns the relevant assets and leases those to the operating company.
} 
new listings", one reason being that "clipping” rather than "stapling”, and the external subordinated debt requirement, reduces the potential agency and financial distress cost beefits.

As Avi-Yonah et al (2007), and others, predicted explicitly stapled securities became popular as a means of achieving the same tax arbitrage as income (or business) trusts, and have led to legislation in July 2011 to prevent those practices. That legislation ${ }^{22}$ prevents publicly listed entities with stapled structures involving debt securities from accessing tax deductibility of interest on such debt for company tax purposes. It also specifically precludes REITs from using stapled securities, in order to prevent the REIT from undertaking business activities outside those specifically permitted by legislation.

There are relatively few examples of use of stapled securities in other countries. De Jong, Rosenthal and van Dijk (2009) find two examples of stapling used in dual listed company structures. $^{23}$

"Smithkline Beecham issued "equity units" (consisting of 5 class B ordinary shares stapled to one preferred share) to the former shareholders of the U.S. based Smithkline Beckham Group, while former shareholders of Beecham Group PLC (a U.K. company) received class A ordinary shares in the new company. The dividends to one class A share are equalized to the dividends of one stapled equity unit.” De Jong et al (2009, p498).

The Eurotunnel Group involved a structure where shares in Eurotunnel P.L. and the French sister company, Eurotunnel S.A. were stapled, with investors having units which comprised one share of each.

One recent example of stapling has been in the 2010 restructuring of one of Iceland's banks (Straumur Burdaras) following the Global Financial Crisis. As outlined by Myles (2010), stapling of debt and equity securities had two benefits. First, it enabled trading of the securities by international investors on international clearing systems. Second, because the debt securities were treated by the Icelandic authorities as equity for tax

\footnotetext{
22 See Department of Finance Canada (2011)

${ }^{23}$ While the published version of the paper referenced here only refers to the SmithKine Beecham case, earlier versions of the paper also included Eurotunnel.
} 
purposes, payments to international holders were taxed at a more favourable dividend withholding tax rate than the tax rate which would otherwise have occurred.

Stapled structures have been listed on the Singapore Stock Exchange, both through crosslisting on that exchange of Australian entities listed on the ASX (SP Ausnet), but also via IPOs of such entities in Singapore (CDL Hospitality Trust). In Hong Kong, at the end of 2011, PCCW announced that it would be spinning off its telecommunications business by creating a business trust involving an issue of stapled securities comprising an ordinary share in the operating company, a preference share in the ordinary company and a unit in a trust.

The Malaysian Bank, Maybank, issued RM 3.5 billion of stapled securities in June 2008, involving a non-cumulative preference share and a subordinated note, which qualified as non-innovative Tier 1 hybrid capital. (Maybank, 2012)

\section{Conclusion}

Australian authorities, unlike most of their international counterparts, have not seen fit to introduce restrictions which prevent Australian entities from issuing stapled securities. One of the main regulatory concerns regarding stapling is its use for tax arbitrage when differential taxation is applied to different entities. In particular, the co-existence of tax "pass through" entities such as trusts with companies operating under a classical or incompletely integrated company tax system provides structuring opportunities to reduce the double taxation of dividends. In the case of Australia, the dividend imputation tax system operates to remove double taxation of dividends (for Australian residents) and thus reduces or eliminates incentives for this type of tax arbitrage. And where tax arbitrage is possible, such as via the stapled securities issued by banks, the effect is to reduce foreign company tax paid and increase Australian company tax paid. Consequently tax based incentives for regulatory actions by the Australian authorities have not been substantial. ${ }^{24}$

\footnotetext{
${ }^{24}$ However, in December 2011, the Federal Court gave a ruling (which is under appeal) denying the ability of CBA to provide franking credits on its stapled PERLS V security on the grounds that the intention of the structure was primarily tax driven.
} 
In contrast, in other countries with non-fully integrated tax systems, there are strong incentives to prevent dilution of the corporate income tax base through the creation of stapled structures which involve trusts which are taxed on a "flow through" basis. Other countries also have incentives to act against structures initiated on the basis of international tax arbitrage such as those used by Australian banks which involve leakage from those countries corporate tax receipts. Thus whether such innovations are likely to survive is open to question, particularly also given the changes to capital requirements under Basel III which reduce the ability of banks to use hybrid instruments to meet those requirements.

In the case of stapling arrangements by A-REITS and Infrastructure Funds in Australia, there are few potential tax benefits apparent from stapling. Whether non-tax benefits exist is an unresolved question. While there are a range of potential benefits (as discussed in Section 2 above), their actual economic significance warrants further study. This is particularly so if it is believed that much of the rationale for creation of stapled structures is the exploitation of investor information deficiencies to effect wealth transfers towards the creators and managers of such structures - as RiskMetrics (2008) have argued in the case of infrastructure funds. 


\section{REFERENCES}

Alarie, Benjamin and Edward M. Iacobucci (2007) “Tax Policy, Capital Structure And Income Trusts” The Canadian Business Law Journal Volume 45, No. 1 June 2007

Avi-Yonah, Reuven, Tim Edgar, and Fadi Shaheen, 2007, Stapled Securities - "the Next Big Thing” for Income Trusts? Useful Lessons from the US Experience with Stapled Shares, Canadian Tax Journal (2007) Vol.55, No.2, 247-88

Davis, K. (2009) "Infrastructure Trust Financial Management", JASSA, March 2009, 4347

de Jong, Abe, Rosenthal, Leonard and Mathijs A. van Dijk (2009) "The Risk and Return of Arbitrage in Dual-Listed Companies” Review of Finance, 13, 495-520, 2009.

Denton, S. N. R (2011) “Hong Kong - Introducing Business Trusts and Stapled Securities” Martindale.com Legal Library, http://www.martindale.com/businesslaw/article_SNR-Denton_1382802.htm (accessed 13 Jan 2012)

Department of Finance Canada (2011) Backgrounder: Amendments to the Taxation of Specified Investment Flow-Through Entities, Real Estate Investment Trusts and PubliclyTraded Corporations, July 20, 2011, http://www.fin.gc.ca/n11/data/11-058_1-eng.asp

Dimovski, W (2010) “The Underpricing Of A-Reit Ipos In Australia During 2002 To 2008” Pacific Rim Property Research Journal, Vol 16, No 1, 2010

Finnerty, J and D Emory (2002) “Corporate Securities Innovation: An Update” Journal of Applied Finance, Spring/Summer 21-47.

Halpern Paul and Oyvind Norli, 2006, Canadian Business Trusts: A New Organizational Structure, Journal of Applied Corporate Finance, Summer 2006, Volume 18, No. 3, 6675

HM Revenue and Customs (2010) CFM90310 - Debt cap: groups affected: groups with stapled stock, http://www.hmrc.gov.uk/manuals/cfmmanual/cfm90310.htm (accessed 15/1/12).

Inland Revenue NZ (2009) Other Policy Matters: Stapled Stock, http://www.ird.govt.nz/technical-tax/legislation/2009/2009-34/2009-34-other-policymatters/2009-34-op-stapled+stock/ (accessed 15/1/12)

Maybank (2012) http://www.maybank.com/investor-relations/outstanding-bonds (accessed 15/1/12)

Miller, Merton H. (1995) "Do the M\&M Propositions Apply to Banks?" Journal of Banking and Finance; 19(3-4), June 1995, pages 483-89. 
Myles, D (2010) “Stapling key to Iceland Restructuring first” IFLR, September 28, 2010, http://www.iflr.com/Article/2678524/Channel-Sector-News-and-deals/Stapling-key-toIceland-restructuring-first.html (accessed 15/1/2011)

Newell, G., and Peng, H.W. (2009), “The Impact of the Global Financial Crisis on AREITs”. Pacific Rim Property Research Journal, 15(4), 453 - 470.

Povel, P. and R. Singh (2010), "Stapled Finance”. The Journal of Finance, 65: 927-953. doi: 10.1111/j.1540-6261.2010.01557.x

RiskMetrics (2008) Infrastructure Funds: Managing, Financing and Accounting, In Whose Interests?

Shefrin H and M Statman (1993) "Behavioural Aspects of the Design of Financial Products” Financial Management, 11, 2, Summer, 1993, 123-134

Yong, Jaime Li Ping “Integration Of Stapled A-Reit, Stock And Bond Returns” http://ssrn.com/abstract=1663684 


\section{APPENDIX 1}

\begin{tabular}{|c|c|c|c|c|}
\hline Ticker & Company & Category & $\begin{array}{c}\text { Stock } \\
\text { Exchange }\end{array}$ & $\begin{array}{c}\text { Year of } \\
\text { Issue }\end{array}$ \\
\hline ABP & Abacus Property Group & Property Trusts & ASX & 2002 \\
\hline APA & APA Group & Infrastructure Funds & ASX & 2006 \\
\hline APZ & Aspen Group & Property Trusts & ASX & 2003 \\
\hline BBC & Babcock \& Brown Communities & Property Trusts & ASX & 2007 \\
\hline BBI & Babcock \& Brown Infrastructure Group & Infrastructure Funds & ASX & 2002 \\
\hline BBP & Babcock \& Brown Power & Infrastructure Funds & ASX & 2006 \\
\hline BBW & Babcock \& Brown Wind Partners & Infrastructure Funds & ASX & 2005 \\
\hline BLP & Babcock \& Brown Residential Land partners & Property Trusts & ASX & 2006 \\
\hline CDI & Challenger Diversified Property & Property Trusts & ASX & 2006 \\
\hline CER & Centro Retail Group & Property Trusts & ASX & 2005 \\
\hline CEU & ConnectEast Group & Infrastructure Funds & ASX & 2004 \\
\hline $\mathrm{CHC}$ & Charter Hall Group & Property Trusts & ASX & 2005 \\
\hline CIF & Challenger Infrastructure Group & Infrastructure Funds & ASX & 2005 \\
\hline CKP & Cheviot Kirribilly Vineyard property Group & Property Trusts & ASX & 2006 \\
\hline CMW & Cromwell Corporation Limited & Property Trusts & ASX & 2006 \\
\hline CNP & Centro Properties Group & Property Trusts & ASX & 2004 \\
\hline $\mathrm{CXH}$ & Compass Hotel Group & Property Trusts & ASX & 2007 \\
\hline DXS & DEXUS Property Group* & Property Trusts & ASX & 2004 \\
\hline DUE & DUET Group & Infrastructure Funds & ASX & 2004 \\
\hline ENV & Envestra Limited & Infrastructure Funds & ASX & 1997 \\
\hline GMG & Goodman Group & Property Trusts & ASX & 2004 \\
\hline GPT & GPT Group & Property Trusts & ASX & 2007 \\
\hline HDF & Hastings Diversified Utilities Fund & Infrastructure Funds & ASX & 2004 \\
\hline HLG & Hedley Leisure and Gaming Property Fund & Property Trusts & ASX & 2007 \\
\hline IOF & ING Office Fund & Property Trusts & ASX & 2000 \\
\hline LEP & ALE Property Group & Property Trusts & ASX & 2003 \\
\hline \multirow[t]{2}{*}{ MAP } & Macquarie Airports & Infrastructure Funds & ASX & 2002 \\
\hline & Macquarie Communications Infrastructure & & ASX & \\
\hline MCG & Group & Infrastructure Funds & & 2002 \\
\hline MCQ & Macquarie Capital Alliance Group & Private Equity & ASX & 2005 \\
\hline MGR & Mirvac Group & Property Trusts & ASX & 1999 \\
\hline MIFS & MacarthurCook Industrial Property Fund & Property Trusts & ASX & 2007 \\
\hline MIG & Macquarie Infrastructure Group & Infrastructure Funds & ASX & 1996 \\
\hline MIT & Mariner Pipeline Income Trust & Infrastructure Funds & ASX & 2006 \\
\hline MLE & Macquarie Leisure & Property Trusts & ASX & 2003 \\
\hline MMG & Macquarie Media Group & Specialist & ASX & 2005 \\
\hline MPG & Macquarie Private Capital Group & Private Equity & ASX & 2005 \\
\hline MPY & MFS Living and Leisure Group & Property Trusts & ASX & 2006 \\
\hline REU & Rubicon Europe Trust Group & Property Trusts & ASX & 2005 \\
\hline SGP & Stockland & Property Trusts & ASX & 1988 \\
\hline SKI & Spark Infrastructure Group & Infrastructure Funds & ASX & 2005 \\
\hline & & & ASX/Singap & \\
\hline SPN & SP AusNet & Infrastructure Funds & ore & 2005 \\
\hline TCL & Transurban Group & Infrastructure Funds & ASX & 1996 \\
\hline TCQ & Trinity Limited & Property Trusts & ASX & 2004 \\
\hline TGP & Trafalgar Corporate & Property Trusts & ASX & 2005 \\
\hline THG & Thakral Holdings Group & Property Trusts & ASX & 1994 \\
\hline
\end{tabular}




$\begin{array}{lllcr}\text { TSI } & \text { Transfield Services Infrastructure Fund } & \text { Infrastructure Funds } & \text { ASX } & 2007 \\ \text { VIR } & \text { Viridis Clean Energy Group } & \text { Infrastructure Funds } & \text { ASX } & 2005 \\ \text { VPG } & \text { Valad Property Group } & \text { Property Trusts } & \text { ASX } & 2002 \\ \text { WDC } & \text { Westfield Group } & \text { Property Trusts } & \text { ASX } & 2004 \\ & & \text { Non-LMIs } & \text { ASX/Singap } & \\ \text { ALZ } & \text { Australand Property Group } & \text { Non-LMIs } & \text { ASX } & 2003 \\ \text { MXG } & \text { Multiplex Group ** } & & \text { Singapore } & 2003 \\ \text { CDL } & \text { CDL Hospitality Trusts } & & \end{array}$

* Its previous trading name is DB RREEF Trust, which acquired Deutsche Bank's 50\% interest in its management company, DB RREEF Funds Management Ltd, and rebranded to DEXUS Property Group in December 2007.

** Muliplex Group was delisted from ASX in December 2007, followed by the acquisition by Brookfield Asset Management Inc. 